\title{
PEMANFAATAN LIMBAH PENCUCIAN IKAN SEBAGAI PUPUK ORGANIK CAIR UNTUK PERTUMBUHAN TANAMAN CABAI RAWIT (Capsicum annum)
}

\section{UTILIZATION OF FISH WASHING AS A LIQUID ORGANIC FERTILIZER FOR THE GROWTH OF CHILI PEPPER(Capsicum annum)}

\author{
Usman $^{1)}$, Rida Oktorida Khastini ${ }^{1)}$, Siti Nursiska Widianti ${ }^{1)}$ \\ ${ }^{1)}$ Program Studi Pendidikan Biologi Fakultas Keguruan dan Ilmu Pendidikan \\ Universitas Sultan Ageng Tirtayasa \\ Email: usman@untirta.ac.id (penulis korespondensi)
}

\begin{abstract}
ABSTRAK
Penelitian ini bertujuan untuk mengetahui konsentrasi limbah cair pencucian ikan yang tepat sebagai pupuk organik bagi pertumbuhan tanaman cabai rawit. Penelitian ini merupakan penelitian eksperimen dengan 6 taraf konsentrasi limbah cair dan 3 ulangan dengan menggunakan rancangan acak lengkap (RAL). Taraf konsentrasi pemupukan yang digunakan yaitu $0 \%$ (kontrol), 3,5\%, 4\%, 4,5\%, 5\%, $5,5 \%$ dan $6 \%$. Parameter pertumbuhan cabai rawit yang diukur adalah tinggi batang, jumlah helai daun dan jumlah bunga. Data hasil penelitian dianalisis menggunakan Analisis of Varians (ANOVA) dengan uji lanjutan menggunakan Duncan Multipe Range Test (DMRT). Hasil penelitian menunjukkan bahwa pemberian pupuk organik limbah pencucian ikan berpengaruh nyata terhadap pertumbuhan tanaman cabai rawit dengan konsentrasi $5 \%$.
\end{abstract}

Kata Kunci: limbah pencucian ikan; pupuk organik cair; cabai rawit

\section{ABSTRACT}

The objective of this study was to determine the fish processing waste water used as organic fertilizer on the growth of pepper plant. This study was an experimental study with 6 levels concentration of waste water and 3 replications using a completely randomized design. The fertilization concentrations levels used in were $0 \%$ (control), 3\%, 4\%, 4,5\%, 5\%, 5,5\%, and 6\%. The growth of papper plant was observed through steam height, number of leaves and number of flowers. The data from the study were analyzed using Analysis of Variance (ANOVA), and followed by Duncan's Multipe Range Test (DMRT). The results showed that organic fertilizer from the fish processing waste water significantly affected the growth of pepper plants with a concentration of $5 \%$.

Keywords: fish washing waste; liquid organic fertilizer; chilli pepper

\section{PENDAHULUAN}

Indonesia merupakan negara maritim yang kaya sumber daya alam terutama ikan. Ikan merupakan sumber protein yang penting bagi masyarakat Indonesia. Proses pengolahan ikan oleh masyarakat umumnya akan membuang bagian yang tidak dikonsumsi misalnya sisik dan organ dalam ikan. Hal ini 
dapat menimbulkan masalah lingkungan. Limbah berupa padatan, cairan, atau gas bila tidak dikelola dan diolah dengan baik menimbulkan ketidaknyamanan bagi manusia, bahkan mencemari dan merusak lingkungan (Indriani et al., 2013).

\section{Limbah cair (liquid waste)} dapat didefinisikan sebagai suatu limbah hasil kegiatan yang secara fisik berbentuk cair, kandungannya didominasi oleh air beserta bahanbahan kontaminan lainnya atau didominasi oleh bahan cair lain (bukan air), seperti: minyak, residu senyawa-senyawa kimia dan sebagainya (Fitria, 2008). Limbah cair perikanan mengandung banyak protein dan lemak sehingga mengakibatkan nilai nitrat dan amonia yang cukup tinggi. Pemanfaatan sumber bahan organik dari hewan dengan memanfaatkan limbah cair perikanan bisa menjadi salah satu alternatif sebagai bahan baku pupuk organik cair.

Menurut hasil penelitian Zahroh (2018) perbandingan variasi konsentrasi pupuk organik limbah ikan memberikan pengaruh yang signifikan terhadap pertumbuhan jumlah daun dan tinggi batang tanaman cabai merah (Capsicum annum). Perlakuan optimal dari perbandingan variasi konsentrasi pupuk organik cair limbah ikan terhadap pertumbuhan jumlah daun dan tinggi batang tanaman cabai merah pada konsentrasi 4,5\%. Penelitian Fitriani membuktikan bahwa pamanfaatan limbah ikan sebagai pupuk cair limbah organik berpengaruh nyata terhadap diameter batang dan jumlah polong. Pada penelitian ini dengan pemberian dosis $0,5 \%$ pupuk cair limbah organik menjadi dosis yang efektif untuk diaplikasikan pada tanaman kacang hijau. Berdasarkan peneliti sebelumnya bahwa limbah perikanan dapat dijadikan sebagai pupuk organik cair yang dapat digunakan tumbuhan sebagai unsur hara tambahan.

Produksi tanaman cabai rawit di Indonesia belum mencapai potensi ideal yang dapat memenuhi kebutuhan baik dalam negeri maupun kebutuhan ekspor. Menurut Alviana dan Susila (2011) rata-rata produksi cabai nasional baru mencapai 4,35 ton/ha, sementara potensi produksi cabai rawit dapat mencapai 10 ton/ha, sedangkan 
menurut Duriat (2012) potensi hasil tanaman cabai dapat mencapai 12-20 ton/ha. Produktivitas cabai rawit di Indonesia rata-rata masih rendah. Pada tahun 2009 produksi cabai rawit 5,07 ton/ha, pada tahun 2010 turun menjadi 4,56 ton/ha, dan pada tahun 2013 produksi menjadi 5,01 ton/ha. Berdasarkan data dari Badan Pusat Statistik (2014) tersebut maka perlu adanya peningkatan produktivitas tanaman cabai rawit di Indonesia. Produktivitas tanaman ini dapat ditingkatkan salah satunya melalui dengan pupuk cair organik. Peningkatan produksi cabai rawit bisa juga dilakukan dalam skala rumah tangga, dengan cara menanam cabai di pekarangan rumah. Untuk meningkatkan produksinya bisa menggunakan pupuk yang dihasilkan dari limbah rumah tangga, salah satunya adalah limbah cucian ikan.

Pupuk cair yang dibuat dari limbah cucian ikan bersifat organik. Penggunaan pupuk organik diharapkan dapat memperbaiki kesuburan tanah sekaligus menyediakan unsur hara yang dibutuhkan oleh tanaman komoditas pertanian (Ganefati, et al., 2014). Pupuk organik cair memiliki kelebihan yaitu mampu menyediakan unsur hara dan mengatasi defisiensi hara secara cepat. Kelebihan lainnya dari penggunaan pupuk organik cair adalah tidak merusak tanah, tanaman dan lingkungan serta tidak berdampak buruk pada kesehatan manusia walaupun penggunaanya dilakukan secara terus menerus. Berdasarkan pemaparan tersebut maka penilitian ini dilakukan yang bertujuan untuk mengukur pengaruh penggunaan pupuk cair organik dari limbah cucian ikan terhadap pertumbuhan tanaman cabai rawit.

\section{METODE}

Penelitian dilakukan pada bulan Mei 2019-Januari 2020. Pengambilan bahan baku limbah pencucian ikan di TPI (Tempat Pelelangan Ikan) Pelabuhan Perikanan Nusantara Karangantu Serang-Banten. Proses pembuatan pupuk limbah pencucian ikan dan uji kandungan hara pupuk organik dilakukan di labolatorium.

Alat yang digunakan dalam adalah alat gelas, sprayer, botol plastik ukuran 1,5 liter, polybag ukuran $3 \mathrm{~kg}$, penggaris, gayung, dan lanjar/ajir. Bahan yang digunakan adalah limbah cair perikanan, tanah 
kompos, air bersih, gula merah, EM4 (Effective microorganisme 4), dan benih biji cabai rawit (Capsicum annum) varietas Pelita 8 F1.

Penelitian menggunakan percobaan Rancangan Acak Lengkap (RAL) yang terdiri dari 7 perlakuan dan 3 kali ulangan sehingga ada 21 unit percobaan. Konsentrasi pemupukan yang digunakan sebagai berikut: $0 \%$ (kontrol), 3,5\% (35 ml pupuk dalam $1000 \mathrm{ml}$ larutan), 4\% (40 ml pupuk dalam $1000 \mathrm{ml}$ larutan), 4,5\% (45 ml pupuk dalam $1000 \mathrm{ml}$ larutan), 5\% (50 ml pupuk dalam $1000 \mathrm{ml}$ larutan), 5,5\% (50 ml pupuk dalam $1000 \mathrm{ml}$ larutan), 6\% (60 ml pupuk dalam $1000 \mathrm{ml}$ larutan).

Penelitian dimulai dengan cara fermentasi EM4 $100 \mathrm{ml}$ dengan air bersih $1000 \mathrm{ml}+$ gula pasir $10 \mathrm{~g}$, dihomogenkan lalu difermentasi selama 2 hari dengan mengacu pada Fauzi (2015). Proses ini bertujuan untuk mengembangbiakan dan mengaktifkan mikroorganisme yang ada pada EM4 dari kondisi dorman, sehingga mikroorganisme dapat bekerja dengan optimal.

Limbah pencucian ikan yang dihasilkan dari ekstrak isi perut ikan sebanyak $1000 \mathrm{ml}$ kemudian ditambahkan dengan EM4 yang sudah difermentasi, setelah semuanya tercampur lalu dihomogenkan dan difermentasi selama 2 hari sampai muncul aroma alkohol sebagai hasil fermentasi (Suaib, et al., 2012). Fermentasi dilakukan agar kandungan unsur hara pada limbah cair perikanan terurai menjadi unsur hara, sehingga tanaman mampu menyerap unsur hara tersebut. Pupuk organik cair yang sudah dibuat diuji kandungan hara meliputi $\mathrm{N}$ total, $\mathrm{C}$ organik, $\mathrm{C} / \mathrm{N}$ rasio, $\mathrm{P}$ tersedia, $\mathrm{K}$ total dan $\mathrm{pH}$.

Benih yang digunakan adalah cabai rawit (Capsicum annum) varietas Pelita 8 F1. Sebelum disemai benih cabai rawit diseleksi yang bagus dan tidak cacat dengan indikasi ketika direndam benih tidak terapung (Alex, 2013). Setelah sterilisasi biji dikeringkan kemudian ditebarkan pada tempat penyemaian.

Persiapan media tanam yang digunakan yaitu dari campuran tanah dan kotoran hewan dengan perbandingan 1:1 lalu dimasukan ke dalam nampan/tray. Biji yang telah direndam disemai dengan cara semai baris yaitu ditaburkan pada baris persemaian pada media tanah kompos. Penyemaian dilakukan 
selama 30-45 hari sampai bibit cabai rawit berdaun 4-6 helai dan siap dipindahkan ke polybag. Penyemaian dilakukan selama 14 hari atau telah memiliki 4 helai daun, disiram setiap pagi dan sore hari.

Bibit cabai dipilih yang baik yaitu pertumbuhannya segar, warna daun hijau, tidak cacat atau terkena hama penyakit. Selanjutnya menyiapkan tempat penanaman berupa polibag yang sudah diisi tanah kompos sebanyak $1 / 4$ dari volume polybag. Pemindahan bibit cabai rawit dilakukan pada sore hari untuk menghindari kematian akibat suhu yang yang tinggi (Tonny, 2011). Bibit diletakkan di tempat yang tersinari matahari dan disiram secukupnya untuk menjaga kelembaban. Penyiraman dengan air biasa dilakukan secukupnya setiap pagi dan sore hari agar tidak kekeringan atau terlalu lembab.

Media tanaman yang gunakan adalah campuran tanah dan kotoran hewan dengan perbandingan 1:1 lalu dimasukan ke dalam tray. Biji yang sudah direndam disemai dengan cara semai baris. Pemberian pupuk dilakukan 3 hari setelah semaian pindah ke polybag dengan cara disemprotkan menggunakan sprayer.
Pemberian pupuk selanjutnya dilakukan 2 hari sekali selama 1,5 bulan.

Data yang diamati adalah jumlah daun, tinggi batang $(\mathrm{cm})$ dan jumlah bunga $(\mathrm{cm})$. Data yang diukur dan dikumpulkan dalam penelitian ini adalah sebagai berikut: jumlah daun dihitung pada helaian daun yang telah membuka dengan sempurna. Tinggi batang diukur dengan menggunakan mistar, mulai dari pangkal batang hingga titik tumbuh pucuk apikal. Perhitungan jumlah bunga dilakukan setelah tanaman berbunga dan dihitung satuan.

Hasil pengamatan dianalisis menggunakan ANOVA satu faktorial pada tingkat signifikan 5\% dan untuk mengetahui ada tidaknya beda nyata antara perlakuan konsentrasi pupuk limbah cair perikanan dilanjutkan dengan uji DMRT (Duncan Multipe Range Test) pada taraf 5\%. Analisis data pada penelitian ini dilakukan dengan menggunakan program SPSS versi 24. 
HASIL DAN PEMBAHASAN

\section{Kandungan Hara Limbah Cair} Buatan

Pupuk cair organik limbah pencucian ikan yang sudah diformulasikan kemudian dianalisis di laboratorium. Hasil analisis kandungan pupuk organik dapat dilihat pada tabel 1 .

Tabel 1. Hasil Analisis Kandungan Hara Pupuk Organik Cair

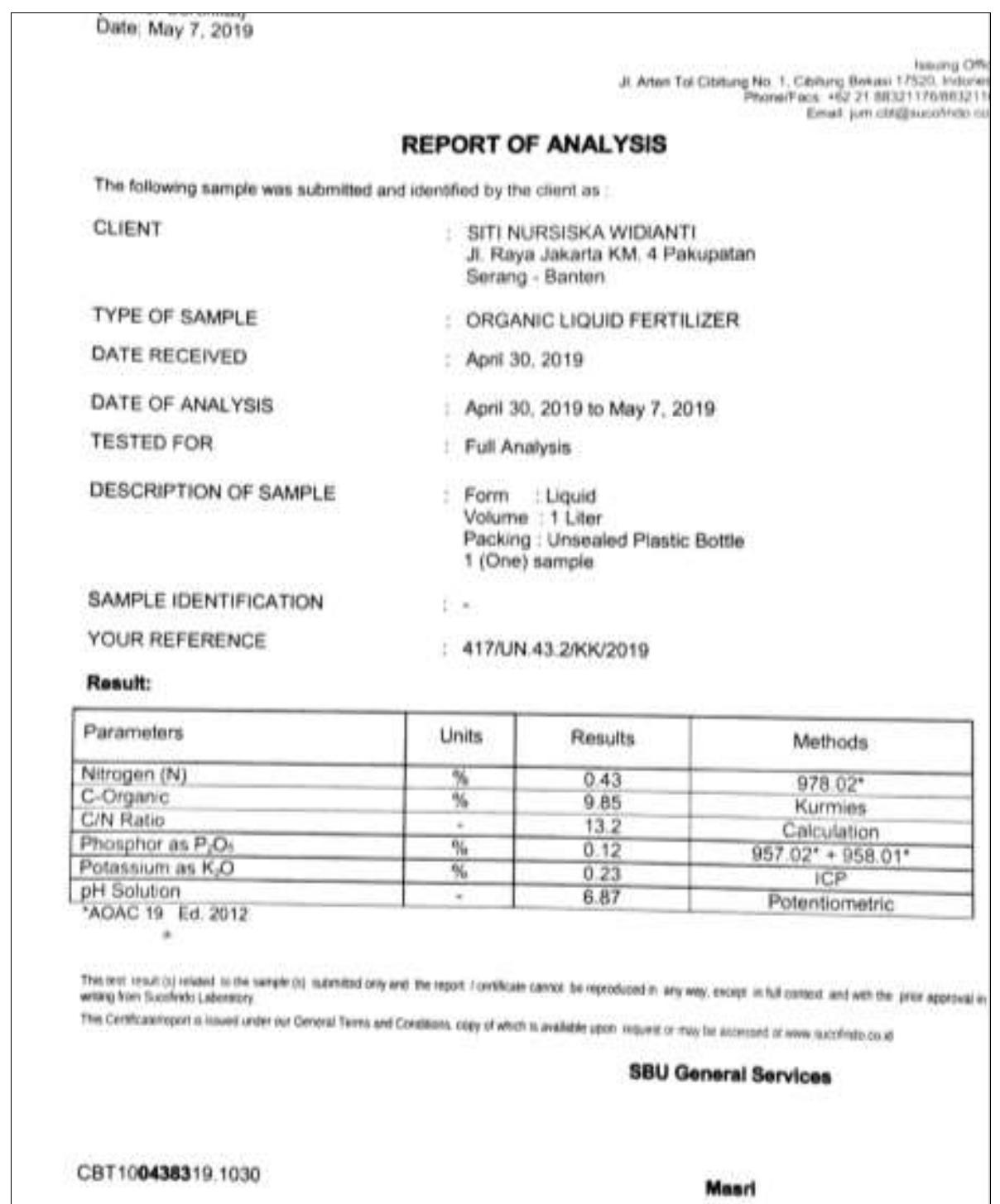

Berdasarkan tabel 1 dapat diketahui bahwa kandungan unsur hara pupuk organik limbah cair pencucian ikan memenuhi standar kualitas pupuk organik berdasarkan SNI 19-0730-2004. Rata-rata 
kandungan $\mathrm{N}$ total dalam pupuk organik cair adalah $0,43 \mathrm{mg} / \mathrm{ml} . \mathrm{N}$ total merupakan jumlah nitrogen yang terkandung bersifat organik maupun anorganik (Jenie \& Rahayu, 2015).

Total C organik yang diperoleh sebesar 9,85\%. C organik merupakan bahan organik yang mempengaruhi kesuburan tanah yang berperan bagi pertumbuhan tanaman. Nilai $\mathrm{C} / \mathrm{N}$ limbah cair buatan adalah 13,2. Nilai $\mathrm{C} / \mathrm{N}$ yang rendah $(\mathrm{C} / \mathrm{N}<5) \quad$ menunjukkan ketersediaan senyawa karbon yang rendah. Karbon merupakan sumber energi yang digunakan oleh mikroorganisme untuk mengikat nitrogen. Nilai $\mathrm{C} / \mathrm{N}$ yang rendah akan mengganggu proses penguraian bahan organik yang disebabkan oleh keterbatasan senyawa karbon yang tersedia dan pupuk organik yang dihasilkan akan memiliki kualitas yang rendah (Nugroho, 2013).

Kandungan $\mathrm{P}$ tersedia limbah cair pencucian ikan sebesar 0,12 $\mathrm{mg} / \mathrm{ml}$. Berdasarkan standar nasional pupuk organik kandungan hara $\mathrm{P}$ tersedia memiliki nilai >0,10 maka dapat diketahui bahwa kandungan $\mathrm{P}$ tersedia dalam pupuk organik cair sudah memenuhi standar nasional.
Kandungan $\mathrm{K}$ tersedia pada pupuk organik cair limbah pencucian ikan yaitu sebesar $0,23 \%$ sehingga sudah memenuhi kualitas pupuk organik berdasarkan standar nasional, yaitu $>0,20 \%$. Ketersediaan kalium bagi tanaman dibagi menjadi $\mathrm{K}$ tidak tersedia ( $\mathrm{K}$ dalam batuan mineral), $\mathrm{K}$ lambat tersedia (K yang tidak dapat dipertukarkan) dan $\mathrm{K}$ tersedia (K yang dapat dipertukarkan dan $\mathrm{K}$ dalam larutan tanah). $\mathrm{K}$ yang dapat dipertukarkan adalah $\mathrm{K}$ dalam bentuk organik (Buckman \& Brady, 1982).

Nilai pH limbah cair pencucian ikan sebesar 6,67. Nilai pH limbah cair buatan ini hampir sama dengan hasil analisis nilai $\mathrm{pH}$ yang dilaporkan oleh Fauzi, et al. (2015) yaitu 6,95. Menurut Jenie dan Rahayu (2015) efluen dari industri pengolahan ikan mempunyai $\mathrm{pH}$ mendekati 7.

\section{Respon Pertumbuhan dan Perkembangan Tanaman Cabai Rawit (Capsicum annum)}

Hasil pengukuran tinggi tanaman cabai rawit dari beberapa perlakuan menunjukkan adanya perbedaan yang dapat dilihat pada Gambar 1. 


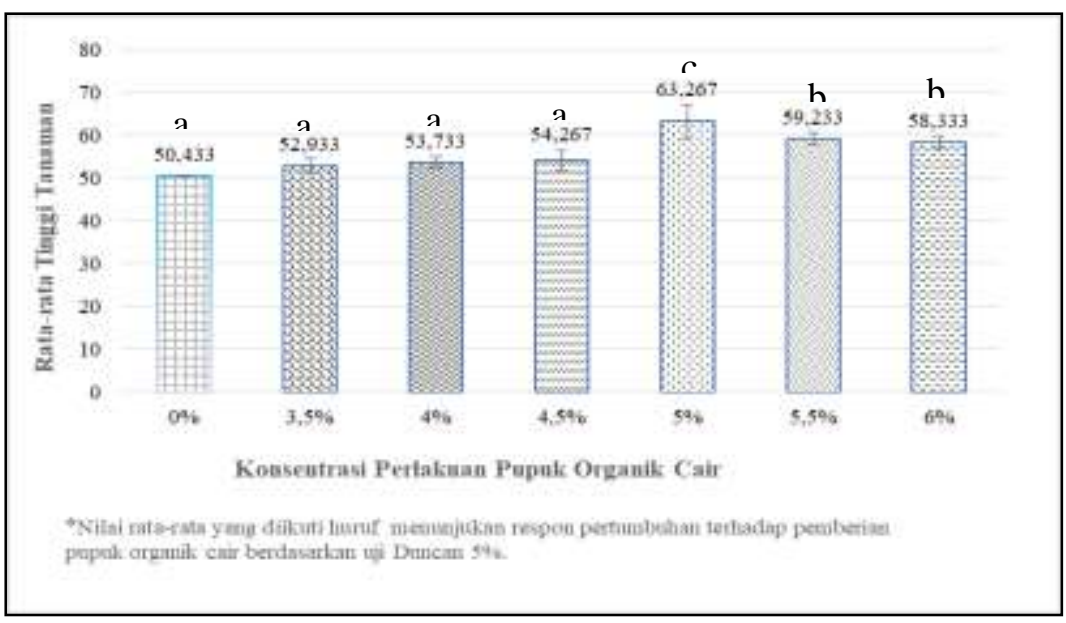

Gambar 1. Tinggi Tanaman Cabai Rawit

Gambar 1 menunjukkan bahwa perlakuan konsentrasi pemupukan memberikan respon yang berbeda.
Tinggi tanaman cabai rawit yang paling tinggi ditunjukkan oleh konsentrasi pemupukan 5\%.

Tabel 3. Hasil Uji Duncan Pertumbuhan Tingga Tanaman Cabai Rawit

\begin{tabular}{ccccc}
\hline \multicolumn{5}{c}{$\begin{array}{c}\text { Tinggi Tanaman } \\
\text { Duncan }\end{array}$} \\
Konsentrasi & $\mathrm{N}$ & \multicolumn{2}{c}{$\begin{array}{c}\text { Subset for alpha }=0.05 \\
2\end{array}$} & 3 \\
\hline $0 \%$ & 3 & 50.433 & & \\
$3.5 \%$ & 3 & 52.933 & & \\
$4 \%$ & 3 & 53.733 & & \\
$4.5 \%$ & 3 & 54.267 & 58.333 & \\
$6 \%$ & 3 & & 59.233 & \\
$5.5 \%$ & 3 & & & 63.267 \\
$5 \%$ & 3 & & .597 & 1.000 \\
\hline Sig. & & .050 & & \\
\hline
\end{tabular}

Hasil uji Duncan pada tinggi tanaman cabai rawit menunjukkan bahwa perlakuan pupuk konsentrasi 3,5\%, $4 \%$ dan $4,5 \%$ tidak berbeda secara signifikan terhadap perlakuan kontrol (0\%), begitu juga dengan konsentrasi $6 \%$ dan 5,5\% keduanya tidak signifikan terhadap kontrol $(0 \%)$. Konsentrasi pemupukan $5 \%$ berpengaruh signifikan dengan pemberian pupuk yang lainnya dan mengakibatkan tinggi cabai rawit paling tinggi yaitu $63.267 \mathrm{~cm}$. 


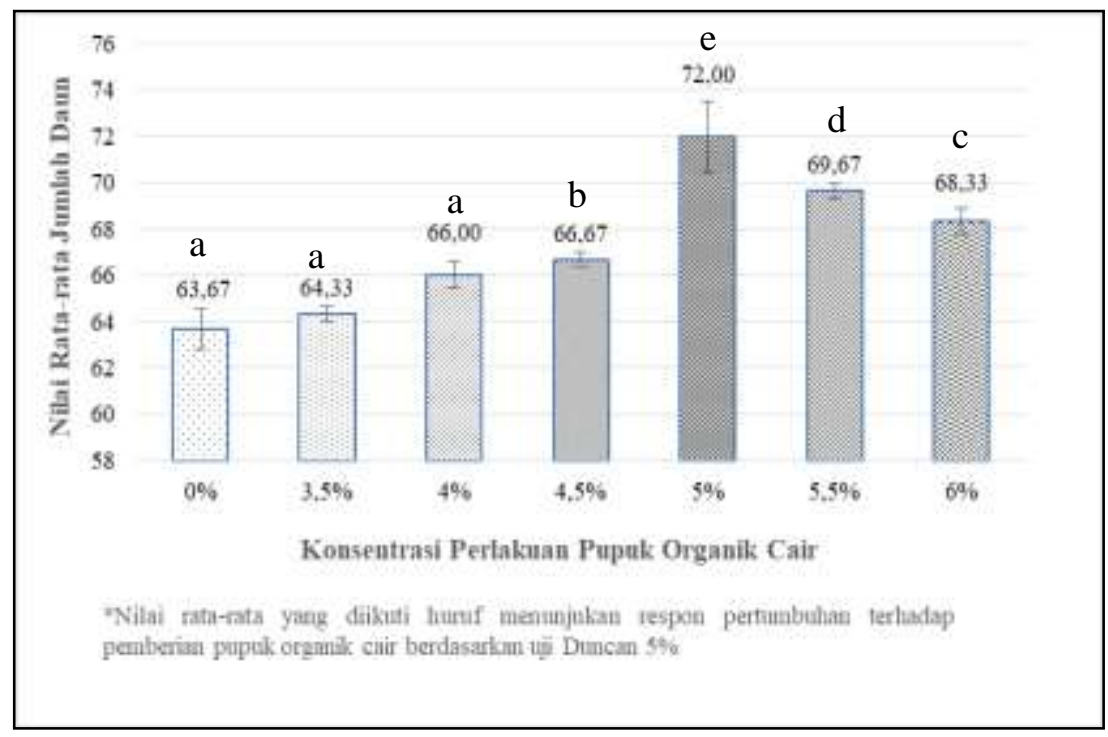

Gambar 2. Jumlah Daun Cabai Rawit

Jumlah daun pada tanaman cabai rawit menunjukkan adanya variasi pengaruh pemberian pupuk cair limbah pencucian ikan. Konsentrasi pupuk 5\% memberikan pengaruh yang signifikan dibandingkan konsentrasi yang lainnya. Perlakuan konsentrasi 5,5\% dan $6 \%$ tidak signifikan tetapi signifikan dengan perlakuan tanpa pemberian pupuk organik cair kontrol (0\%). Jumlah daun yang diberi pupuk limbah cair pencucian ikan $3,5 \%$ dan $4 \%$ tidak signifikan dibanding tanaman kontrol, tetapi konsentrasi $4,5 \%$ memberikan pengaruh signifikan dibanding perlakuan kontrol.

Tabel 4. Hasil Uji Duncan Jumlah Daun Tanaman Cabai Rawit

\begin{tabular}{ccccccc}
\hline \multirow{2}{*}{$\begin{array}{c}\text { Duncan } \\
\text { Konsentrasi }\end{array}$} & $\mathrm{N}$ & \multicolumn{5}{c}{ Subset for alpha = 0.05 } \\
& & 1 & 2 & 3 & 4 & 5 \\
\hline $0 \%$ & 3 & 63.67 & & & & \\
$3.5 \%$ & 3 & 64.33 & 64.33 & & & \\
$4 \%$ & 3 & 66.00 & 66.00 & 66.00 & & \\
$4.5 \%$ & 3 & & 66.67 & 66.67 & & \\
$6 \%$ & 3 & & & 68.33 & 69.33 & \\
$5.5 \%$ & 3 & & & & & 72.00 \\
$5 \%$ & 3 & & & & & \\
\hline Sig. & & .053 & .053 & .053 & .227 & 1.000 \\
\hline
\end{tabular}

Perlakuan pupuk konsentrasi $3,5 \%$ dan $4 \%$ tidak signifikan dengan kontrol (0\%) tetapi signifikan dengan perlakuan pupuk 
cair konsentrasi 4,5\%. Konsentrasi $6 \%$ dan 5,5\% tidak signifikan, tetapi signifikan dengan kontrol $(0 \%)$ dan konsentrasi $3,5 \%$, $4 \%$ dan $4,5 \%$. Daun cabai rawit dengan pemberian pupuk organik konsentrasi 5\% signifikan dengan kontrol $(0 \%)$ dan konsentrasi lainnya, yang memperoleh nilai paling besar yaitu 72,00 .

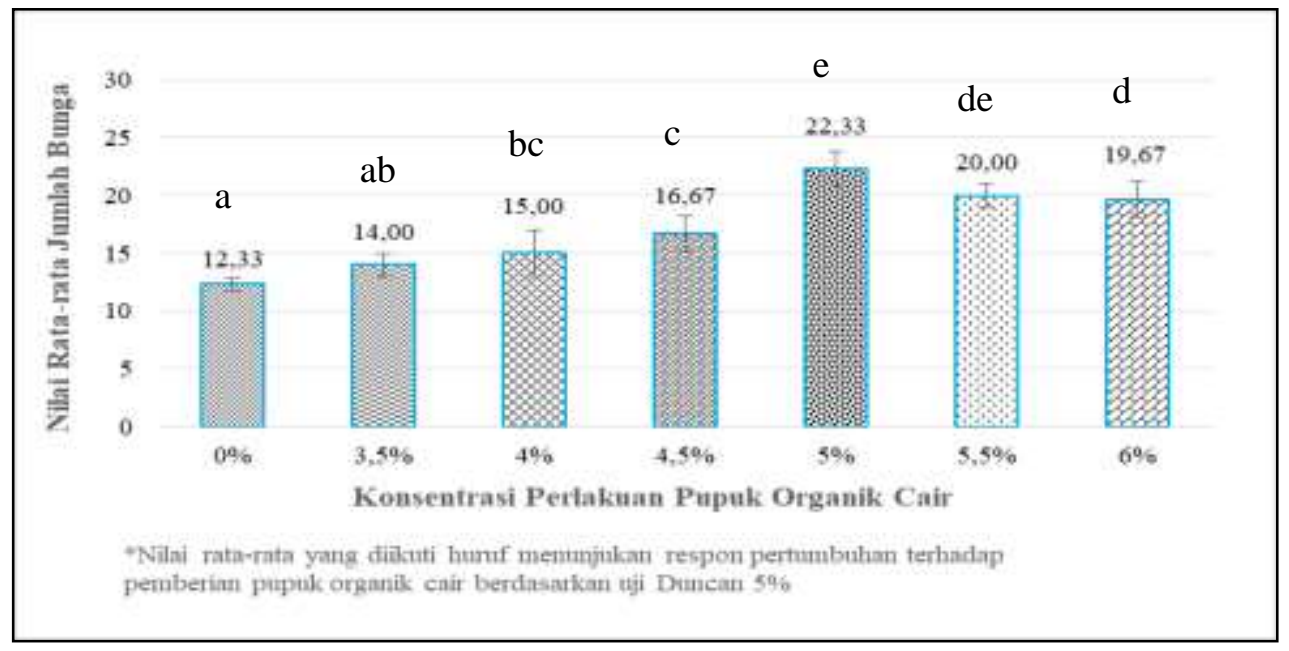

Gambar 3. Jumlah Bunga Cabai Rawit

Jumlah bunga cabai rawit menunjukkan adanya variasi akibat pemberian pupuk cair limbah pencucian ikan. Pada konsentrasi pupuk 3,5\% memberikan pengaruh yang tidak signifikan dibanding tanaman kontrol begitu juga dengan konsentrasi 4\%, tetapi signifikan dengan pemberian pupuk konsentrasi
$4,5 \%$. Pemberian pupuk organik cair limbah pencucian ikan dengan konsentrasi 5\% tidak signifikan dengan perlakuan konsentrasi 5,5\% dan $6 \%$, tetapi signifikan dengan konsentrasi 5,5\% dan 6\%. Bunga cabai rawit terbanyak diperoleh akibat pemberian pupuk konsentrasi $5 \%$, yaitu sebanyak 22,3. 
Tabel 7. Hasil Uji Duncan Jumlah Bunga Cabai Rawit

\begin{tabular}{|c|c|c|c|c|c|c|}
\hline \multicolumn{7}{|c|}{ Jumlah Bunga } \\
\hline Duncan & & & & & & \\
\hline \multirow{2}{*}{ Konsenrasi } & \multirow[t]{2}{*}{$\mathrm{N}$} & \multicolumn{5}{|c|}{ Subset for alpha $=0.05$} \\
\hline & & 1 & 2 & 3 & 4 & 5 \\
\hline $0 \%$ & 3 & 12.33 & & & & \\
\hline $3.5 \%$ & 3 & 14.00 & 14.00 & & & \\
\hline $4 \%$ & 3 & & 15.00 & 15.00 & & \\
\hline $4.5 \%$ & 3 & & & 16.67 & & \\
\hline $6 \%$ & 3 & & & & 19.67 & \\
\hline $5.5 \%$ & 3 & & & & 20.00 & 20.00 \\
\hline $5 \%$ & 3 & & & & & 22.33 \\
\hline Sig. & & .161 & .390 & .161 & .772 & .057 \\
\hline
\end{tabular}

Hasil uji Duncan menunjukkan

hasil bahwa pemberian pupuk organik cair konsentrasi 3,5\% tidak signifikan dengan perlakuan kontrol (0\%), konsentrasi $4 \%$ tidak signifikan dengan konsentrasi 3,5\%, konsentrasi $4,5 \%$ tidak signifikan terhadap konsentrasi 4\%. Konsentrasi $6 \%$ dan $5,5 \%$ keduanya tidak signifikan, konsentrasi $5 \%$ tidak signifikan dengan 5,5\%, tetapi dapat dilihat bahwa jumlah bunga cabai rawit paling banjk yaitu pada konsentrasi 5\% dengan nilai 22,33.

Pada fase vegetatif seperti pertumbuhan batang dan daun, unsur hara yang paling banyak dibutuhkan adalah nitrogen $(\mathrm{N})$, sebab unsur nitrogen dalam pupuk cair berperan penting dalam proses pembentukan klorofil yang berguna dalam proses fotosintesis. Proses fotosintesis ini berfungsi untuk memperoleh dan juga menghasilkan makanan bagi tanaman, dengan kandungan klorofil yang cukup dapat memacu pertumbuhan tanaman terutanama dalam merangsang organ vegetatif pada suatu tanaman (Purwadi, 2011).

Ketersediaan nitrogen yang terserap oleh tanaman dapat dipenuhi dari proses fermentasi bahan baku limbah ikan. Konsentrasi pupuk organik cair limbah ikan untuk pertumbuhan tanaman cabai yang optimal adalah konsentrasi $5 \%$.

Pertumbuhan yang baik bagi tanaman cabai rawit adalah konsentrasi $5 \%$ dapat didukung pula oleh ketersediaan makronutrien lainnya, seperti karbon, oksigen, hidrogen, nitrogen, fosfor, kalium, kalsium, dan sulfur yang dibutuhkan untuk siklus hidup tanaman dan menghasilkan generasi yang lain (Campbell, 2012: 373). Tanaman 
cabai rawit seperti pada umumnya tanaman lain, akan sehat jika unsur hara tersebut terpenuhi. Makronutien dapat tersedia pada proses fermentasi bahan primer yang mencakup limbah cair ikan sebagai pupuk yang diaktivasi oleh mikroba EM4 (Effective microorganisme 4) yang menguntungkan bagi pertumbuhan tanaman.

\section{KESIMPULAN}

Konsentrasi pupuk organik cair limbah pencucian ikan berpengaruh secara signifikan terhadap pertumbuhan tanaman cabai rawit yakni tinggi batang, jumlah daun dan jumlah bunga. Pemberian pupuk organik cair dari limbah ikan dengan konsentrasi $5 \%$ merupakan konsentrasi pupuk yang paling efektif pada pertumbuhan dan perkembangan pada tanaman cabai rawit (Capsicum annum).

\section{DAFTAR PUSTAKA}

Alex, S. 2012. Sukses Mengolah Sampah Organik Menjadi Pupuk Organik. Pustaka Baru Press. Yogyakarta.

Alvian, V., F. \& A., D. Susila. 2011. Optimasi Dosis Pemupukan pada Budidaya Cabai (Capsicum annum)
Menggunakan Irigasi Tetes dan Mulsa Polyethylene. Jurnal Agronomi Indonesia. 7 (1): 28-33.

Buckman, H.O. \& N.C. Brady. 1982. Ilmu Tanah. Bhratara Karya Aksara. Jakarta.

Fauzi, Y. 2015. Budidaya Pemanfaatana Hasil Limbah dan Analisis Usaha Pemasaran. Cetakan Pertama Penebar Swadaya. Jakarta.

Jenie B.S.L. \& W. P. Rahayu. 2015. Penanganan Limbah Industri Pangan. Kanisius. Yogyakarta.

Nugroho, P. 2013. Panduan Membuat Pupuk Kompos Cair. Pustaka Baru Press. Yogyakarta.

Purwadi, E. 2011. Batas Krisis Suatu Unsur N dan Pengukuran Kandungan Pada Tanaman. url://masbied.com. Diakses pada tanggal 14 Agustus 2019 pukul 20:09 WIB.

Suaib, A. A. \& L. Kurniawari. 2012. Pemanfatan Residu Bahan Organik dan Fofor untuk Budidaya Tanaman Kacang Panjang (Vigna radiata). Penelitian Agronomi. 1 (1): 8-15.

Tonny. 2011. Budidaya Cabai Merah di Bawah Naungan untuk Menekan Serangan Hama dan penyakit. Yayasan Bina Tani Sejahtera, Bandung Bara. 